\title{
ROSYJSKIE I POLSKIE ELITY RZĄDZĄCE WOBEC ZAGADNIENIA OBRONY PRZECIWRAKIETOWEJ NATO/USA * CZĘŚĆ 2
}

\section{The Approach of the Russian and Polish Ruling Elites to the Issue of NATO/US Missile Defence System. Part 2}

Polish-Russian relations are among the most difficult and the most complicated neighbourly relations in Europe. They are difficult particularly for Poland, but they are also complicated for Russia. The relations have a difficult history and Poland has more often experienced Russian domination, falling victim to Russia's imperial policy. These negative experiences have evoked mutual suspicion and distrust in the elites of both countries.

After the collapse of communism and the Soviet Union, Poland set out to integrate with the Euro-Atlantic structures, such as NATO and the European Union (EU). Poland's accession to NATO was meant to strengthen its national security and international position, protecting it from potential Russian neo-imperialism and making it an important element (particularly in Central and Eastern Europe) of a monocentric, US-dominated global order. The attempts made by Russia and the West to achieve mutual agreement in the 1990s ended in failure. Russia is afraid of American hegemony in the world and its progressive marginalisation, and it thus opposes the expansion of NATO to the East. On the other hand, Poland and the Baltic states are afraid of Moscow's military campaigns, such as those in Georgia and Ukraine. The location of Poland and Russia in global geopolitics makes their interests collide with each other.

Artykuł napisany przy wsparciu Centrum Porozumienia i Dialogu Polsko-Rosyj- 
To increase its security, Poland strengthens cooperation with Washington and strives to actively participate in all American projects implemented under the auspices of NATO with regard to Central and Eastern Europe. One such project is the construction of NATO's missile defence system on the territory of Poland, which raises Russia's serious objections. The article presents the attitude of Russia and Poland to the creation of the NATO missile defence system. It analyses bilateral perception, argumentation, fears and methods of achieving goals in negotiations regarding the construction of the American missile shield.

Keywords: Russia, Poland, USA, NATO, international security, missile defence system.

\section{NOWE CZYNNIKI BEZPIECZEŃSTWA MIĘDYNARODOWEGO A SYSTEM OBRONY PRZECIWRAKIETOWEJ}

Amerykański sekretarz obrony Chuck Hagel 15 marca 2013 roku ogłosił wprowadzenie zmian do planów budowy tarczy antyrakietowej - rezygnację $z$ czwartego etapu tworzenia europejskiej OPR i koncentrację USA na regionie Azji i Pacyfiku w celu ochrony swojego terytorium przed szybko rosnacym zagrożeniem rakietowonuklearnym ze strony Korei Północnej. Sprzyjały temu zarówno ograniczenia finansowe, jak i techniczne. Po pierwsze, Kongres zmniejszył wydatki na tworzenie systemu antyrakietowego. Po drugie, eksperci z Pentagonu oraz amerykańskiej Izby Obrachunkowej, którzy ocenili perspektywy europejskiej OPR, zakwestionowali jej skuteczność. Najsłabsze elementy tego systemu to krótki zasięg radarów i niezdolność rakiet przechwytujących do wybrania celu. W przekonaniu ekspertów europejskie radary OPR nie sa w stanie wykryć pocisków balistycznych w początkowej fazie lotu, a czujniki zamontowane na rakietach przechwytujących nie moga odróżnić prawdziwej głowicy od fałszywych celów (systemów obronnych rakiet) ${ }^{1}$.

Rezygnacja $z$ czwartego etapu tworzenia europejskiego segmentu globalnej OPR nie usunęła wszystkich rosyjskich obaw związanych $z$ obrona antyrakietowa NATO w Europie, oświadczył rosyjski $\mathrm{MSZ}^{2}$. W rzeczywistości dla Rosji nic się nie zmieniło, elementy OPR z Europy zostały przeniesione na Wschód, co wyraził z niezadowoleniem wiceminister spraw zagranicznych Siergiej Riabkow. Powiedział

Проблематика ПРО, „МИД РФ”, 16 stycznia 2014. 
również, że nawet okrojona europejska OPR może stanowić zagrożenie dla rosyjskiego potencjału nuklearnego, biorąc pod uwage fakt, że elementy OPR zachowuja wysoka mobilność ${ }^{3}$.

Po aneksji Krymu przez Rosję i wybuchu działań wojennych w Donbasie jedna $z$ reakcji w USA na te wydarzenia były głosy o potrzebie przyspieszenia prac nad budowa tarczy antyrakietowej, zwłaszcza na terenie Polski ${ }^{4}$. Nie stało się tak jednak ze względu na czynniki finansowe, techniczne i polityczno-strategiczne. Ponadto USA nie zamierzały intensyfikować konfrontacji z Moskwą ${ }^{5}$.

W ramach NATO w sierpniu 2014 roku cztery kraje Europy Środkowo-Wschodniej - Polska, Litwa, Estonia i Łotwa - miały wezwać innych członków NATO do przyjęcia formuły wskazującej, że oprócz ochrony przed pociskami balistycznymi z Bliskiego Wschodu, celem istnienia europejskiej OPR jest również powstrzymywanie Rosji. Jednak inni sojusznicy, zwłaszcza Niemcy, byli przeciwni temu, pamiętając o obietnicy NATO, że tak się nie stanie ${ }^{6}$. Oznaczałoby to oczywiście zerwanie umowy NATO-Rosja, która ogranicza rozmieszczenie znaczacych sił i sprzętu wojskowego w Europie Środkowo-Wschodniej. Rosja podjęłaby wówczas znaczące kroki wobec Europy, na przykład wyjście $z$ traktatu INF (likwidacji rakiet średniego i krótkiego zasięgu).

Zgodnie $z$ rezultatami szczytu NATO w Warszawie z 2016 roku strony zgodziły się rozwijać współpracę $z$ krajami trzecimi (domyślnie Rosja) w celu zwiększenia przejrzystości, wiarygodności i skuteczności OPR. Może to oznaczać wymianę informacji, konsultacje i współpracę $^{7}$. Po raz kolejny stwierdzono, że OPR NATO nie jest wymierzona w Rosję. Jednak ta część oświadczenia ma charakter wyłącznie dyplomatyczny, nie ma na celu rozwiazania problemu, ale koryguje stare zapisy. NATO oświadczyło, że nie jest gotowe pójść na ustępstwa wobec Rosji w tej sprawie, mając na uwadze, że Rosja także nie zmieni swojego negatywnego stanowiska w sprawie OPR.

3 США меняют прописку ПРО, „Коммерсант”, 18 marca 2013.

4 K. Czornik, Tarcza antyrakietowa jako jeden z gwarantów bezpieczeństwa Polski, w: Dylematy polityki bezpieczeństwa Polski na początku drugiej dekady XXI wieku, red. M. Stolarczyk, K. Czornik, M. Lakomy, Katowice 2014, s. 161-190.

5 M. Fryc, Rozwój amerykańskiego systemu przeciwrakietowego $w$ Europie - czy możliwe jest przyspieszenie budowy tarczy? „Bezpieczeństwo Narodowe” 2014, III, s. 31-50.

„Der Spiegel”, 25 August 2014.

Заявление по итогам встречи на высшем уровне в Варшаве, 9 liрса 2016. To samo zostało wyartykułowane również w Deklaracji ws. bezpieczeństwa transatlantyckiego na warszawskim szczycie NATO, www.nato.int. 
Potwierdza to oświadczenie prezydenta Polski Andrzeja Dudy, z 2016 roku podczas uroczystości wmurowania kamienia węgielnego pod budowę tarczy antyrakietowej w Redzikowie:

Nie mamy żadnego interesu w powrocie do zimnej wojny. Potrzebujemy intensywnego dialogu, aby zmniejszyć ryzyko błędów, uniknąć konfliktów i zwiększyć przewidywalność naszych relacji ${ }^{8}$.

Jednak dialog z Federacją Rosyjską „nie powinien w żaden sposób wpływać" na porozumienia w ramach NATO dotyczące wspólnych kwestii obronnych - powiedział Andrzej Duda9. Oznacza to, że w rzeczywistości Polska na żadne kompromisy wobec Moskwy nie pójdzie, a współpraca jest możliwa tylko wtedy, gdy Rosja uzna rozwój OPR w Polsce za fakt.

Po rezygnacji przez USA $z$ czwartego etapu tworzenia europejskiej OPR istniały szanse na kontynuację dialogu w kwestii OPR z Rosja, aby rozwiać jej obawy. Ale było mało prawdopodobne, aby porozumienie zostało osiagnięte do marca 2014 roku. Jednak wydarzenia ukraińskie ostatecznie przekreśliły te szanse. Nawet gdy w sierpniu 2016 roku NATO przejęło dowodzenie amerykańską tarczą antyrakietowa w Europie, nadzieje Waszyngtonu, że można tym rozwiać rosyjskie obawy, okazały się płonne. Rosja w ogóle na to nie zareagowała. To samo stało się w kwietniu 2018 roku, kiedy dyrektor Agencji Obrony Antyrakietowej, generał Samuel Greaves, powiedział, że ze względu na małe postępy prac $\mathrm{w}$ Polsce, uruchomienie systemu baterii antyrakiet zostało przeniesione z 2018 na 2020 rok. Dla Moskwy neutralizacja realnej obecności OPR USA w Europie Środkowo-Wschodniej stała się jednym $z$ elementów definiujących rosyjska politykę wojskowa.

\section{ARGUMENTY POLSKI}

Po pierwsze, jak już wspomniano, powodem rozmieszczenia OPR USA w Europie było zagrożenie ze strony Iranu. W 2006 roku szef polskiego Biura Bezpieczeństwa Narodowego, generał Stanisław Koziej, stwierdził:

Jest oczywiste, że Iran nie dysponuje rakietami o zasięgu ponad 2 tys. $\mathrm{km}$.

I także Korea Północna. Nie możemy jednak myśleć o tym, co jest teraz,

8 Польша вдруг захотела мира, „Утро”, 19 таја 2016.

9 „Свободная пресса”, 18 maja 2016. 
ale o tym, co będzie się działo w przyszłości. A analiza pokazuje, że zagrożenia rakietowe będą wzrastać ${ }^{10}$.

Błędnej oceny irańskiego zagrożenia rakietowego dowodzi również wypowiedź polskiego attaché wojskowego w Moskwie, Andrzeja Lewandowskiego, $z$ lutego 2007 roku:

Iran w latach 2010-2013 będzie dysponował pociskami balistycznymi o zasięgu ponad 6 tys. km. Baza obrony przeciwrakietowej na terytorium Rzeczypospolitej Polskiej, jeżeli zostanie podjęta decyzja o jej lokalizacji, zostanie zbudowana w latach 2011-2012 ${ }^{11}$.

Jest oczywiste, że obawy związane $z$ zagrożeniem ze strony Iranu były znacznie przesadzone. Minęło 11 lat, a Iran nie opracował jeszcze pocisku o zasięgu ponad 2 tys. $\mathrm{km}$. Analizy polska i amerykańska nie były trafne. Rozwój irańskiej rakiety Sajjil-2 na paliwo stałe o zasięgu 2 tys. $\mathrm{km}$ napotkał problemy techniczne. Ponadto irańscy politycy publicznie stwierdzili, że kraj „nie potrzebuje pocisków o zasięgu ponad 2 tys. km"12. Jednak polski MON wciąz podkreślał, że balistyczne zagrożenie dla regionu euroatlantyckiego znacznie wzrośnie w przyszłości ${ }^{13}$. Uwzględniając ograniczony rozwój programu budowy rakiet balistycznych i nie ulegajacca zmianie retorykę dotycząca przyszłych zagrożeń rakietowych, można stwierdzić, że tezy te maja charakter polityczny, a nie techniczny.

Drugim powodem tworzenia OPR w Polsce jest rozwój własnego lotnictwa. Polska ma przestarzałe środki obrony powietrznej, pochodzace głównie $z$ czasów sowieckich. Ich dalsza modernizacja jest zwykle uważana za nieuzasadnioną technicznie i finansowo ${ }^{14}$. Jest to faktem i dlatego też sa podejmowane działania na rzecz stworzenia krajowej OPR i OPL (obrony przeciwlotniczej) w Polsce. Jednak $\mathrm{w}$ tej sytuacji zastrzeżenia Polski wobec rozwoju militarnego Rosji staja się nieuzasadnione. W państwie tym także w latach dziewięćdziesiątych XX wieku nie przeprowadzano modernizacji uzbrojenia

10 Amerykańska tarcza antyrakietowa a interes narodowy Polski-dyskusja, Fundacja im. Stefana Batorego, 7 sierpnia 2006, s. 7-8, http://www.batory.org.pl/upload/files/pdf/ tarcza-antyrakietowa.pdf

11 „Корреспондент”, 6 lutego 2007.

12 M. Elleman, Iran's Ballistic Missile Program, Statement Before the U.S. Senate Committee on Banking, Housing, and Urban Affairs, 24 May 2016.

13 Polish Perspectives on Missile Defense, CEPA, 7 March 2013, http:/ / cepa.org/index/ ?id=061f193d29d6ec5b5c02ed242396c2a7

14 Ibidem. 
armii, dopiero po 2000 roku rozpoczą się proces unowocześniania rosyjskich sił zbrojnych.

Trzecie uzasadnienie tworzenia OPR w Polsce jest zwiąane $z$ polskimi aspiracjami do przywództwa w Europie Środkowo-Wschodniej. Ekspert Krzysztof Śliwiński stwierdza, że tarcza antyrakietowa pozwala Polsce na wzmocnienie strategicznego sojuszu z USA, a tak$\dot{z}$ e sprawia, że jest ona liderem w Europie Środkowej i Wschodniej ${ }^{15}$. W rzeczywistości Polska samodzielnie nie jest w stanie prowadzić silnej polityki na Wschodzie. Jest to możliwe tylko dzięki współpracy z NATO. „Im silniejsza będzie pozycja Polski w Brukseli, tym będzie ona dysponowała lepszymi narzędziami do prowadzenia polityki wschodniej" - stwierdził Witold Waszczykowski w 2006 roku $^{16}$.

Czwartym powodem jest wzmocnienie roli Polski w NATO i w sojuszu $z$ USA. Zdając sobie sprawę, że jej miejsce na arenie międzynarodowej zależy od trwałości konstrukcji euroatlantyckich, Polska pod koniec XX wieku cały swój potencjał w polityce zagranicznej ukierunkowała na ich wzmocnienie i dalszy rozwój. Jest aktywnym członkiem tych struktur i wykorzystuje możliwości wniesienia własnych sugestii i propozycji dotyczących różnych aspektów działań NATO. Polska dostrzega w NATO siłę zdolna ja wprowadzić do grona najpotężniejszych i najbardziej wpływowych państw - jeśli nie świata, to przynajmniej regionu.

Jednak decydując się na uczestnictwo w OPR, Polska postrzegała bilateralne stosunki $z$ Waszyngtonem jako bardziej korzystne niż działania w ramach NATO. W istocie obawiała się, że każda próba tworzenia OPR przez NATO na jej terytorium będzie albo blokowana lub spowalniana przez sceptycznych sojuszników, albo ograniczana w wyniku presji ze strony Rosji.

Piąty powód to Rosja i jej powstrzymywanie (odstraszanie). W 2006 roku na temat polskiej percepcji OPR jako środka obrony przed potencjalnym atakiem ze strony Rosji wypowiadali się Grzegorz Gromadzki z Fundacji Batorego i Marcin Kaczmarski z Instytutu Stosunków Międzynarodowych Uniwersytetu Warszawskiego. Ich zdaniem zrozumiałe jest, że po dyslokacji OPR w Polsce, rosyjskie rakiety zostana wycelowane $\mathrm{w}$ Polskę ${ }^{17}$. Wydaje się jednak, że posiadanie ochrony przed Rosja miało fundamentalne znaczenie dla pol-

${ }^{15}$ K. Śliwiński, Polish national security dilemmas: The US missile defense complex and its role in Polish foreign policy, „Democracy and Security” 2012, 8,2, s. 191-212.

${ }_{16}$ Amerykańska tarcza antyrakietowa..., s. 2-5.

17 Ibidem, s. 12-15. 
skich polityków. Jeszcze w 2007 roku premier Jarosław Kaczyński powiedział, że instalacja amerykańskich rakiet przechwytujących na ziemiach polskich zapewni, że kraj nigdy nie znajdzie się w rosyjskiej strefie wpływów ${ }^{18}$. Według polskiego analityka Łukasza Kulesy, w debacie publicznej od poczatku XXI wieku amerykańska (antyirańska) argumentacja na rzecz konieczności budowy tarczy antyrakietowej była $\mathrm{w}$ prasie prezentowana jedynie mimochodem - $\mathrm{w}$ formie dyżurnych fraz. W argumenty te nikt w Polsce - ani przeciwnicy, ani zwolennicy OPR - nie wierzył i nie stosował ich. Kulesa zauważa, że „większość zwolenników polskiego zaangażowania w projekt systemu antyrakietowego jednomyślnie wskazuje na Rosję i jej możliwa politykę w przyszłości”"

Analityk wojskowy Paweł Turczyński pisał w 2011 roku, że rakiety SM-3, na których dyslokację w Polsce zdecydował się Barack Obama, sa najlepszą ochrona przed ewentualnym scenariuszem rosyjskiego ataku na Europę rakietami krótkiego i średniego zasięgu, na przykład $z$ Kaliningradu ${ }^{20}$.

W 2012 roku część polskich elit, zwłaszcza z Platformy Obywatelskiej, zrozumiała, że OPR w Polsce może nieść ze sobą również zagrożenia (przypuszczalnie $z$ Rosji), ale na ogół wspierała polski udział $\mathrm{w}$ projekcie, niezależnie od ewentualnych zagrożeń, które może Polsce przynieść. W opinii Krzysztofa Śliwińskiego, politycy PO nie skupiali się na antyrosyjskim charakterze OPR, a zwracali uwagę na pozytywne elementy zwiazane ze wzmocnieniem partnerstwa $z$ USA, podniesieniem prestiżu kraju w polityce europejskiej i modernizacja polskich sił zbrojnych ${ }^{21}$.

$Z$ kolei partia Prawo i Sprawiedliwość podkreślała militarne aspekty projektu. Liderzy PiS, odwołując się do doświadczeń historycznych Polski, dostrzegali wiele działań Rosji jako potencjalne zagrożenie dla bezpieczeństwa narodowego ${ }^{22}$.

Przydatność OPR dla Polski w celach odstraszania zmniejsza fakt, że OPR ma jedynie ograniczona użyteczność w niektórych scenariuszach dotyczacych problemu bezpieczeństwa Polski wobec za-

\footnotetext{
18 „Premier Kaczyński pośrednio potwierdził, ̇̇e tarcza USA jest skierowana przeciwko Rosji”, „Gazeta.pl”, 21 lutego 2007.

19 А. Кумеса, Досъе по системе противоракетной обороны. Польская перспектива, „Европа” 2007, t. 7, nr 2 (23), s. 91-104.

20 P. Turczyński, Amerykańskie koncepcje tarczy antyrakietowej $w$ Europie, „Zeszyty Naukowe WSOWL" 2011, nr 3 (161), s. 163-181.

21 K. Śliwiński, Polish national...

${ }^{22}$ Ibidem.
} 
grożenia stwarzanego przez Rosję. Obecna konfiguracja OPR została zaprojektowana do walki $z$ ograniczonym atakiem rakietowym, ale nie jest to wiarygodne narzędzie do sygnalizowania determinacji w obronie obszaru NATO przed krajem o ogromnych możliwościach jądrowych i rakietowych, takim jak Rosja ${ }^{23}$. Oznacza to, że bezpieczeństwo Polski w istocie zależy od USA i NATO. Dla Warszawy jest ważne, aby wraz $z$ rozwojem OPR strategia NATO w zakresie odstraszania nie zmieniła się, nie ograniczała się do przechwytywania rakiet, ale też przewidywała odpowiedź z użyciem broni konwencjonalnej i atomowej.

Jednak według Łukasza Kulesy, podejmujac decyzję, aby stać się częścia projektu OPR pod przewodnictwem Waszyngtonu, Polska wyraźnie liczy na zwiększenie swojego potencjału odstraszajacego, chociażby pośrednio. Możliwości OPR i jego zdolność do przechwytywania pocisków balistycznych skierowanych przeciwko Polsce odgrywały jedynie drugorzędną rolę. Polscy politycy nie wierzą, że Polska może stać się celem ataków rakietowych $z$ Bliskiego Wschodu. OPR wraz $z$ obecnością armii USA stał się czynnikiem odstraszającym. To właśnie obecność amerykańskich sił zbrojnych w Polsce pozwoli uniknać ewentualnej agresji w jej kierunku ${ }^{24}$. Takie poglądy można dostrzec w przemówieniach ministra spraw zagranicznych Radosława Sikorskiego z 2008 roku, jak również szefa Biura Bezpieczeństwa Narodowego, generała Stanisława Kozieja ${ }^{25}$.

$Z$ rosyjskiego punktu widzenia nie będzie to jednak miało odstraszającego wpływu na Rosję, jak się sądzi w Polsce. Członkostwo w NATO i sojusz z USA daja Polakom fałszywe poczucie bezpieczeństwa. Tworzenie OPR zaostrza jedynie napięcia $z$ Rosja, pozostajacą od dłuższego już czasu nieufną wobec zachodnich intencji, które sa realizowane mimo braku wiarygodnych powodów do budowy tarczy antyrakietowej. Rosja zareaguje symetrycznie lub asymetrycznie, ale zareaguje - niezależnie od jakościowej lub ilościowej obecności wojsk amerykańskich w Europie. Zwiększenie militarnej obecności USA w Polsce dodatkowo zmotywuje Rosję do jakościowej reakcji na amerykańską obecność wojskową. W tej sytuacji Polska staje się jedynie terenem konfrontacji między dwoma mocarstwami.

23 Ibidem.

24 Ł. Kulesa, Poland and Ballistic Missile Defense. The Limits of Atlanticism, „IFRI Proliferation Papers" 2014, nr 48.

25 R. Sikorski, The Barack Obama Promise: A European View, „The Atlantic Council”, Washington, 19 November 2008. 
Po wydarzeniach na Ukrainie odstraszanie Rosji zostało dodatkowo uargumentowane jako powód do rozmieszczenia OPR. Ekspert wojskowy Mariusz Fryc w 2014 roku stwierdził, że realizacja planu rozwoju antyrakietowej obrony USA w Europie i pojawienie się nowych zagrożeń dla bezpieczeństwa na Ukrainie stworzyły niepowtarzalną szansę dla Polski na osiagnięcie jednego $z$ najważniejszych celów bezpieczeństwa zewnętrznego, jakim jest wzmocnienie wschodniej flanki NATO ${ }^{26}$. Oznacza to, że OPR odegra istotna rolę w polityce NATO polegajacej na powstrzymywaniu Rosji. To Rosja jest agresywnym graczem na wschodzie Europy, a polityka odstraszania pojawiła się w strategicznych dokumentach NATO w odpowiedzi na rosyjska agresję. Dlatego też, gdy sekretarz generalny NATO nadal twierdzi, że program obrony antyrakietowej nie jest skierowany przeciwko Rosji ${ }^{27}$, to w Moskwie nie tylko się w to nie wierzy, ale także szuka ukrytych motywów rozwoju OPR.

\section{ZASTRZEŻENIA ROSJI}

Głównym czynnikiem, który przekonuje Rosję o niebezpieczeństwie ze strony OPR, jest fakt, że jego tworzenie kontynuowano po uregulowaniu sytuacji wokół irańskiego programu jądrowego (odpowiedni „wspólny kompleksowy plan działania” został uzgodniony 14 lipca 2015 roku). Rosja miała nadzieję, że po rozwiązaniu kwestii irańskiej amerykańska OPR w Europie przestanie istnieć. Tak się jednak nie stało. Departament Stanu USA wydał oświadczenie, że podstawowym powodem uzasadniajacym istnienie europejskiej OPR jest zachowanie przez Iran programu rakietowego ${ }^{28}$. W ten sposób Moskwa otrzymała jedynie dowody, że przyczyną budowy OPR nie jest Iran, ale Rosja.

Zostało to dostrzeżone przez polskich ekspertów z Fundacji Pułaskiego. W raporcie z 2015 roku zauważają oni, że z jednej strony w wyniku porozumienia nuklearnego $z$ Iranem zagrożenie nieoczekiwanym atakiem rakietowym $z$ Bliskiego Wschodu zmniejszyło się, $z$ drugiej strony jednak zagrożenie może pojawić się w związku $z$ modernizacja rosyjskich sił rakietowych, naruszeniem przez Moskwę traktatu INF i coraz bardziej nieprzyjazna retoryka w stosun-

\footnotetext{
26 M. Fryc, Rozwój amerykańskiego ...

27 РИА Новости, 13 lutego 2016.

28 „Взгмяд”, 15 lipca 2015.
} 
kach między NATO a Rosja - również w kwestii pocisków balistycznych $^{29}$.

Uruchomienie kompleksu amerykańskiej OPR w bazie w rumuńskim Deveselu w maju 2016 roku rzecznik Pentagonu przy NATO, Robert Bell, ponownie odniósł do Iranu. „Teraz mamy możliwość ochrony NATO w Europie. Irańczycy zwiększaja swoje zdolności i musimy grać $z$ wyprzedzeniem" ${ }^{30}$. Minister spraw zagranicznych Polski, Witold Waszczykowski, powiedział, że prezydent Władimir Putin powinien wiedzieć, że tarcza antyrakietowa w Polsce nie ma nic wspólnego $z$ bezpieczeństwem Rosji; system ten ma na celu ochronę Europy przed atakiem rakietowym $z$ Bliskiego Wschodu ${ }^{31}$.

W odpowiedzi, szef departamentu nieproliferacji i kontroli zbrojeń rosyjskiego MSZ, Michaił Uljanow, oświadczył, że program rakietowy Iranu nie może być wymówką dla tworzenia europejskiej OPR:

Nie jest jasne, na czym opieraja się zarzuty, że irański program rakietowy stanowi zagrożenie. Dla kogo? Jeśli chodzi o USA, to nie jest ono poważne, ponieważ zasięg irańskich rakiet nie przekracza 2 tys. km. Nawet siły amerykańskie w Europie znajduja się w większej odległości od Iranu ${ }^{32}$.

W październiku 2016 roku pierwszy zastępca szefa zarządu operacyjnego Sztabu Generalnego Sił Zbrojnych Federacji Rosyjskiej, generał Wiktor Poznichir, powiedział, że po analizie symulacji komputerowych można stwierdzić, że:

[...] amerykańska decyzja o tworzeniu mobilnej globalnej OPR nie jest związana $z$ odpowiedzią na zagrożenie rakietowe ze strony Iranu i Korei Północnej. Wynika ona przede wszystkim $z$ chęci uzyskania przewagi militarnej nad Rosją i Chinami ${ }^{33}$.

Generał uznał amerykańskie wyjaśnienia, że OPR nie jest wymierzony w Rosję za gołosłowne i niepoparte żadnymi gwarancjami prawnomiędzynarodowymi.

Oczywisty jest fakt, że to nie komplikacje $z$ Iranem sprawiają, że rosyjskie pretensje o charakterze technicznym stają się uzasadnione. Po pierwsze, od 2014 roku Rosja zwraca uwagę na fakt, że na wy-

29 Obrona przeciwrakietowa na świecie - wnioski dla Polski, Fundacja Pułaskiego, Warszawa 2016, https://pulaski.pl/wp-content/uploads/2015/02/raport_obrona_przeciwrakietowa_na_swiecie_wnioski_dla_polski_FKP.pdf

30 „Взгмяд”, 12 maja 2016.

31 „Defence 24”, 29 May 2016.

32 „Взгмяд”, 12 maja 2016.

33 „Независимая газета”, 11 października 2016. 
rzutniach Mk-41 moga być instalowane amerykańskie rakiety Tomahawk, co jest naruszeniem traktatu $\mathrm{INF}^{34}$. Była to reakcja USA, które jako pierwsze wysunęły pretensje do Rosji w związku $z$ rozwojem rakiet naruszających - według Waszyngtonu - traktat INF.

Po drugie, rosyjski Sztab Generalny oświadczył, że „kompleks OPR ma znaczny potencjał antysatelitarny, stwarzając zagrożenie dla funkcjonowania rosyjskiego orbitalnego systemu kosmicznego" ${ }^{\text {"3 }}$.

Po trzecie, ministerstwo obrony oświadczyło, że dyslokacja OPR w Europie „obniża próg użycia broni jądrowej, tworząc iluzję bezkarności nagłego użycia strategicznych broni ofensywnych pod parasolem obrony antyrakietowej"36.

Po czwarte, w Rosji panuje opinia, wyrażona przez prezydenta Władimira Putina, że celem montażu systemów antyrakietowych jest chęć zaangażowania Rosji w wyczerpujący i kosztowny wyścig zbrojeñ $^{37}$. Podobne oświadczenie głosi, że Rosja obecnie widzi swoją odpowiedź na OPR w Europie w tworzeniu i wdrażaniu do służby wojskowej wszelkich systemów rakietowych. Biorąc pod uwage fakt, że międzykontynentalne pociski balistyczne zdolne do pokonywania obrony antyrakietowej i tak są tworzone i wdrażane, należy koniecznie opracować nowe strategie neutralizacji zagrożeń. Można przypuszczać, że chodzi o systemy rakietowe średniego i krótkiego zasięgu.

Sekretarz generalny NATO, Jens Stoltenberg, twierdzi, że instalacje OPR zlokalizowane w Rumunii i Polsce nie stanowią:

[...] żadnego zagrożenia dla rosyjskiego systemu strategicznego odstraszania nuklearnego, tak samo jak geografia i fizyka sprawiaja, że niemożliwe dla systemu antyrakietowego NATO jest zestrzelenie rosyjskich rakiet międzykontynentalnych ${ }^{38}$.

Taki stan rzeczy istnieje tylko w obecnym okresie. Kluczowym problemem $z$ rosyjskiego punktu widzenia jest niepewność co do przyszłych planów USA dotyczących OPR i związanego $z$ nią rozwoju technologii.

${ }^{34}$ Комментарий МИд России в связи с американскими обвинениями в нарушении российской стороной Договора о РСМД, 30 lipса 2014.

35 В. Мухин, Американская ПРО в Европе уже под прииелом Москвы, „Независимая газета", 13 maja 2016.

36 „RT” (wyd. rosyjskojęzyczne), 13 października 2017.

37 „РИА Новости”, 1 сzеrwca 2017.

38 „РБK”, 12 maja 2016. 
Moskwa obawia się, że rakieta przechwytująca SM-3 Block IIB może mieć prędkość maksymalną większa niż $5 \mathrm{~km} / \mathrm{s}^{39}$. Generał Jewgienij Ilin stwierdził, że pocisk przechwytujacy lecacy z prędkościa $5 \mathrm{~km} / \mathrm{s}$ może być $\mathrm{w}$ stanie przechwycić rosyjskie rakiety dalekiego zasięgu, jeśli zostanie wystrzelony $z$ rejonu Bałtyku lub Morza Norweskiego $^{40}$. To samo stwierdza amerykański naukowiec $z$ Lawrence Livermore National Laboratory, Dean Wilkening, dodając, że potencjalne przyszłe rozmieszczenie setki rakiet przechwytujacych GBI i SM-3 Blok IIA/IIB w zasadzie może dać USA możliwość pierwszego uderzenia nuklearnego ${ }^{41}$. Dlatego też Rosja była szczególnie zaniepokojona czwartym etapem tworzenia amerykańskiej OPR. Chociaż został on później anulowany, to nic nie zdoła przeszkodzić w ewentualnym tworzeniu takich systemów w przyszłości.

Jeszcze w 2007 roku szef polskiego Biura Bezpieczeństwa Narodowego, generał Stanisław Koziej, potwierdził, że rozwój technologii antyrakietowej w przyszłości może zmniejszyć prawdopodobieństwo odwetu ze strony Rosji. Jeśli tak, to tarcza antyrakietowa stanie się zupełnie nowa jakościa $\mathrm{w}$ globalnej strategii nuklearnej lub nowym impulsem do jakościowego wyścigu zbrojeń nuklearnych. Obie te opcje Rosja powinna traktować jako niebezpieczne ze względu na swoje interesy narodowe. Dlatego też wydaje się, że tylko szeroki udział Rosji w tym projekcie może zagwarantować możliwość neutralizacji negatywnych, w tym dla Polski, konsekwencji jego tworzenia - pisał Koziej $^{42}$. Już wówczas Polska miała obawy związane $z$ ogłoszeniem przez Rosję możliwości zakończenia wdrażania traktatu INF w przypadku rozwoju OPR. Jeśli Rosja rozmieści taką broń, całe terytorium Polski będzie w jej zasięgu - stwierdził generał Koziej ${ }^{43}$.

Przyszły rozwój OPR budzi w Rosji wielka niepewność, podobnie jak przyszły rozwój irańskiego programu rakietowego stwarza obawy NATO i Polski. Wszystkie strony musza to zrozumieć, formułując swoje zastrzeżenia i szukając możliwości dialogu i kompromisu.

Jedna $z$ takich opcji amerykańscy eksperci $z$ Fundacji Plougshares widzą następująco: Rosja mogłaby wziąc na siebie obowiązek przestrzegania traktatu INF, a USA wstrzymaja budowę tarczy

39 D.A. Wilkening, Does Missile Defence in Europe Threaten Russia? „Survival” 2012, 54,1, s. 49.

40 Ibidem, s. 43.

41 Ibidem, s. 49.

42 S. Koziej, Tarcza antyrakietowa. Dylematy strategiczne, „Znak”, kwiecień 2007, nr 623.

43 Ibidem. 
antyrakietowej w Polsce. Rezygnujac $z$ niepotrzebnego rozmieszczania rakiet przechwytujących $\mathrm{w}$ Polsce, USA mogłyby zaoszczędzić ograniczone zasoby oraz zwiększyć swoje bezpieczeństwo poprzez zmniejszenie napięć w relacjach $z$ Rosją ${ }^{44}$.

Ekspertka niemieckiego Ośrodka SWP, Katarzyna Kubiak, stwierdziła:

Jeśli NATO nadal chce wspierać OPR, nie należy odrzucać projektu współpracy $z$ Rosją. Tylko wtedy, gdy Moskwa będzie przekonana, że OPR NATO nie stanowi zagrożenia dla Federacji Rosyjskiej, system ten zapewni europejskim sojusznikom kompleksowe bezpieczeństwo. Zatem nowy poczatek współpracy $z$ Rosją byłby dobrym posunięciem ${ }^{45}$.

Steven Pifer proponuje, by Rosja w zamian za to, że USA i NATO zrezygnuja $z$ rozmieszczenia antyrakiet SM-3 w Polsce, zaoferowała NATO coś w zamian. Tym „czymś” może być dialog na temat niestrategicznej broni jadrowej lub w innych kwestiach ${ }^{46}$. OPR USA mogłaby zostać usunięta $z$ Polski, gdyby stacjonowała tam na stałe armia amerykańska. Niewielu polskich urzędników lub oficerów wojskowych obawia się ataku rakietowego ze strony Iranu. Polska potrzebuje obecności armii amerykańskiej na swoim terytorium. Kwestia drugorzędna dla Warszawy będzie wówczas, czy jednostki amerykańskie będa obsługiwały rakiety przechwytujace SM-3 oraz systemy obrony przeciwlotniczej, czy wykonywały inne zadania wojskowe ${ }^{47}$.

Jednak nikt nie jest gotowy na dialog. Rosja potrzebuje poczucia zagrożenia, gdyż groźba ze strony Zachodu jest uzasadnieniem autorytarnej polityki obecnej władzy wobec społeczeństwa i elit. Polska także podlega starym chronicznym lękom z przeszłości. Taka postawę Polski wobec Rosji skomentował profesor Uniwersytetu Warszawskiego, Ryszard Zięba, mówiąc:

Kiedy w polityce zagranicznej brakuje adrenaliny, szukamy fikcyjnego zagrożenia w normalnej sytuacji. Oznacza to często irracjonalne zachowanie Polski, w którym podejmowane działania przynoszą więcej strat niż korzyści ${ }^{48}$.

${ }^{44}$ T. Erästö, Between the Shield and the Sword. NATO's Overlooked Missile Defense Dilemma, „Ploughshares Fund Study Report”, June 2017, nr 3.

${ }^{45}$ K. Kubiak, Raketenabwehr: Potentiale einer Kooperation mit Russland, „SWP-Studie", Juli 2017, s. 13.

${ }^{46}$ S. Pifer, Missile Defense - Would the Kremlin Pitch a Deal? „Brookings Institute”, 2 June 2016.

47 Ibidem.

${ }^{48}$ R. Zięba, Podstawowe dylematy polskiej polityki wschodniej, w: Dylematy polityki zagranicznej Polski na poczatku XXI wieku, red. M. Stolarczyk, K. Czornik, M. Lakomy, Katowice 2014, s. 257-284. 
Jednak ponieważ właśnie to, że elity obu krajów sa przepełnione lękami i wzajemną nieufnością, eskalacja zachowań konfrontacyjnych stała się naturalnym przedłużeniem obecnej polityki w relacjach polsko-rosyjskich.

\section{ZAGROŻENIA ZE STRONY ROSJI}

Co zaskakujace, mimo ponad dziesięciu lat rozwoju OPR w Europie i wielu zagrożeń, Rosja reagowała w miarę spokojnie. Jedyna zrealizowana zapowiedzią było opracowanie i rozmieszczenie nowych rodzajów pocisków nuklearnych - zdolnych do przeciwdziałania najnowszym systemom OPR.

Pierwszą koncepcja $z$ odległego już 2008 roku było rozmieszczenie $\mathrm{w}$ Obwodzie Kaliningradzkim systemu rakiet Iskander o zasięgu $500 \mathrm{~km}$, bezpośrednio wpływających na bezpieczeństwo Polski, gdyż mogących niszczyć obiekty w Redzikowie i Warszawie. Według rosyjskiego ministra spraw zagranicznych Siergieja Ławrowa, Rosja rozmieści rakiety Iskander w Obwodzie Kaliningradzkim tylko wtedy, gdy elementy OPR USA w sąsiedniej Polsce i Czechach „zyskają kontury fizyczne" ${ }^{\not 9}$. Ma to nastapić w 2018 roku.

Drugim pomysłem jest rozmieszczenie kompleksu rakietowego S-400 w Obwodzie Kaliningradzkim i objęcie tym systemem obrony powietrznej terytorium Polski. Podchodząc do lądowania, polskie samoloty odnotuja, że znajduja się w strefie rażenia tego systemu ${ }^{50}$. Będzie to dodatkowy czynnik konfliktogenny w stosunkach między Rosją a Polską, który oczywiście będzie aktywnie wykorzystywany przez Polaków zarówno na poziomie krajowym, jak i w ramach UE i NATO do kształtowania oraz umacniania $\mathrm{w}$ tych strukturach polityki odstraszania Rosji.

Ponadto Rosja może skierować na Polskę najnowsze rakiety systemu Kalibr NK startujące $z$ okrętów. Rakiety te moga przenosić zarówno konwencjonalne, jak i jądrowe głowice w zakresach do 1,5 tys. $\mathrm{km}$ (głowice konwencjonalne) i do 2,6 tys. km (głowice jadrowe). Oznacza to, że $z$ każdego punktu Morza Bałtyckiego i Morza Czarnego rakiety te moga osiagnać dowolny cel na terytorium Polski. Rakiety Kalibr NK zostały już skutecznie przetestowane w Syrii, co wywarło silne wrażenie na NATO.

49 „ВВС - русская служба”, 11 listopada 2008.

50 Мнение военного эксперта Владимира Евсеева. „Московский Комсомолец”, 12 таја 2016. 
Kolejną perspektywa jest wycofanie się Rosji $z$ traktatu INF, o czym od 2007 roku mówiło wielu rosyjskich polityków ${ }^{51}$. Decyzja taka będzie stanowić bezpośrednie zagrożenie dla państw europejskich, zwłaszcza dla Polski. Kilkadziesiąt pocisków krótkiego i średniego zasięgu zostanie rozmieszczonych na zachodnich rubieżach Rosji, obejmując zasięgiem bazy rakiet przechwytujących, jak też wszelkie inne bazy, które USA rozmieściły lub rozmieszczą w Europie w ciagu najbliższych kilku lat.

Ponadto w Polskę będa wycelowane strategiczne systemy rakietowe dalekiego zasięgu - najnowsze kompleksy Jars wchodzące właśnie do służby wojskowej. Zastępca szefa Sztabu Generalnego Sił Zbrojnych Federacji Rosyjskiej, generał pułkownik Anatolij Nogowicyn, stwierdził:

Polska, rozmieszczając elementy OPR, naraża się na atak. Jest to absolutny środek nacisku; takie cele sa $z$ zasady niszczone w pierwszej kolejności ${ }^{52}$.

Ponadto Rosja może wyposażyć okręty Floty Bałtyckiej w broń jądrowa, co będzie miało bezpośredni wpływ na OPR USA w Polsce. Konsekwencją takiego stanu rzeczy jest nowa zimna wojna, choć nie na taka skale jak pierwsza. Liczba broni w nią zaangażowanych jest znacznie mniejsza.

Jednak nikt nie obawia się eskalacji nowej zimnej wojny. Współcześni przywódcy Europy zatracili lęk przed wojną. Nikt nie wierzy w prawdziwą konfrontację militarna i dlatego każda ze stron robi to, co uważa za słuszne. Na przykład były minister spraw zagranicznych Polski, Witold Waszczykowski, uważa, że reakcja na „bardzo agresywne zachowanie" rosyjskich władz jest obecność w Europie kontyngentu wojsk USA i NATO ${ }^{53}$. Na swoje działania każda ze stron reaguje militarnie.

\section{ZAKOŃCZENIE}

Problem obrony antyrakietowej jest tylko jednym $z$ problemów w stosunkach Rosji z Polska i NATO. Jak pokazuje niniejsza analiza, jest on także zakładnikiem ogólnego poziomu stosunków między

${ }^{51}$ N. Hughes, P. Zeihan, The INF Treaty: Implications of a Russian Withdrawal, „Stratfor", 22 February 2007.

52 „NEWSru.com”, 15 sierpnia 2008.

53 „Lenta.ru”, 29 maja 2016. 
Rosja a jej zachodnimi partnerami. Wynika to $z$ faktu, że Moskwa uznaje NATO za instytucję nastawiona na konfrontację $z$ Federacja Rosyjską. To samo dotyczy USA.

Rosja nadal postrzega region Europy Środkowej i Wschodniej jako strefę buforowa, w której następuje kolizja interesów Rosji i Zachodu, miejsce, w którym nie może być znacznych sił wojskowych NATO, jednak nie jest to postrzegane jako przygotowanie do wojny. Polska, wspierając tworzenie OPR na swoim terytorium, automatycznie stała się jednym $z$ obiektów wrogiej retoryki Rosji. Jednak rosyjskie groźby wobec Polski sa groźbami pod adresem NATO i USA, które, w przekonaniu Moskwy, wykorzystuja historycznie uwarunkowany negatywny wizerunek Rosji przeciwko niej.

Od początku procesu negocjacyjnego dotyczacego OPR Polska postrzegała ja jako mechanizm odstraszający Rosję. Oczywiście, Moskwa nie mogła tego nie zauważyć. Dlatego też NATO nie powinno było przekonywać Rosji, że tarcza antyrakietowa nie jest skierowana przeciwko niej, ale prowadzić dialog z Moskwą i Warszawą na temat tego, jak uczynić ten system bardziej przejrzystym. Możliwości takie istniały. W latach 2007-2012 Rosja nie tylko groziła, ale także proponowała opcje dialogu, w ramach których OPR mogłaby funkcjonować. Oznacza to, że Rosja pokazała, że nie sprzeciwia się OPR jako takiej, lecz sprzeciwia się pozbawianiu jej prawa głosu w Europie. Rosja chciałaby włączyć się w proces decyzyjny w sprawach bezpieczeństwa europejskiego i być nie tylko obserwatorem, ale także wpływać na sprawy Europy. Jedynie równowaga strategiczna $z$ USA ma większa wartość dla Rosji niż udział w sprawach europejskich. Dlatego też wśród możliwych odpowiedzi Moskwy na tarczę antyrakietowa istnieje tak wiele działań zmniejszających bezpieczeństwo USA: od broni antysatelitarnej, najnowszych rakiet dalekiego zasięgu, po wycofanie się $z$ traktatów INF i START III.

Po 2012 roku i wyborze Władimira Putina na trzecia kadencję pozytywny stosunek do dialogu w sprawie tarczy antyrakietowej ostatecznie się zmienił. Rosja przestała oferować możliwości dialogu. Po wydarzeniach ukraińskich członkowie NATO również przestali postrzegać dialog $z$ Rosja jako celowy. Jednak do tej pory nie wdrożono do końca żadnego ze środków reakcji Rosji, mimo że NATO prawie zakończyło budowę OPR. Powinno to zostać wykorzystane do znalezienia kompromisu. Nawet istnienie OPR może być transparentne dla Rosji, jeśli będzie zapobiegać eskalacji konfrontacji militarnej i brakowi porozumień w zakresie kontroli zbrojeń. I zależy to nie tyl- 
ko od relacji Rosja-NATO, ale także od relacji między Polska a Rosja. Jak pokazuje historia OPR, może to być przedmiotem dialogu, jeśli strony maja pozytywny plan w stosunkach dwustronnych.

Jednak takie warunki wstępne nie sa jeszcze dostępne. W 2018 roku amerykańskie elementy OPR w Europie miały być uruchomione. Wdrożenie tego etapu zakończyłoby tworzenie OPR NATO, co może mieć bezpośredni negatywny wpływ nie tylko na bezpieczeństwo europejskie, ale również na bezpieczeństwo międzynarodowe. Jeśli dialog nie zostanie podjęty i strony nie osiagna kompromisu, oczywiste jest, że Rosja rozmieści system rakietowy Iskander w Obwodzie Kaliningradzkim i ewentualnie podejmie inne kroki militarne, ale należy przyjmować to ze spokojem. Wszak jeszcze pod koniec lat sześćdziesiatych XX wieku USA również wycelowały swoje rakiety w sowieckie radary i OPR wokół Moskwy. Jedynie wzajemne postrzeganie Rosji i USA jako przeciwników uratuje świat od nieprzemyślanych działań i zbyt pochopnych reakcji. W miejsce starych i niezrealizowanych przez obie strony porozumień z 1997 roku konieczne jest budowanie nowych relacji oraz zawieranie nowych umów uwzględniających fakt, że NATO i Rosja sa obecnie przeciwnikami. Można zacząć od spraw dotyczących transparentności ich działan wojskowych. $\mathrm{Na}$ przykład Federacja Rosyjska może zapraszać przedstawicieli NATO na swoje ćwiczenia wojskowe, a NATO pozwolić Rosji na przeprowadzanie kontroli elementów OPR. Obie strony moga porozumieć się $\mathrm{w}$ kwestii prowadzenia bezpiecznych i transparentnych działań wywiadowczych zarówno w powietrzu, jak i na morzu. Możliwe jest również, że strony w dalszym ciagu będa prowadzić negocjacje, nawet $\mathrm{w}$ tak wąskiej materii jak OPR, w kontekście współczesnej polityki bezpieczeństwa w Europie, wykazując zrozumienie dla swoich racji. Obecna skrajna sytuacja, przypominająca rok 1962 (kubański kryzys rakietowy), może ułatwić dialog między Rosją a NATO. Inne skuteczne opcje nie sa jeszcze widoczne. 